\title{
Biogenesis of endosome-derived transport carriers
}

\author{
Richard J. Chi ${ }^{\# 1,2}$, Megan S. Harrison ${ }^{\# 1}$, and Christopher G. Burd ${ }^{1}$ \\ ${ }^{1}$ Department of Cell Biology, Yale School of Medicine, SHM C425B, 333 Cedar Street, New \\ Haven, CT 06520, USA \\ \# These authors contributed equally to this work.
}

\begin{abstract}
Sorting of macromolecules within the endosomal system is vital for physiological control of nutrient homeostasis, cell motility, and proteostasis. Trafficking routes that export macromolecules from the endosome via vesicle and tubule transport carriers constitute plasma membrane recycling and retrograde endosome-to-Golgi pathways. Proteins of the sorting nexin family have been discovered to function at nearly every step of endosomal transport carrier biogenesis and it is becoming increasingly clear that they form the core machineries of cargo-specific transport pathways that are closely integrated with cellular physiology. Here, we summarize recent progress in elucidating the pathways that mediate the biogenesis of endosome-derived transport carriers.
\end{abstract}

\section{Keywords}

SNX-BAR; Retromer; Fission; Endosome; Recycling; Retrograde; Sorting

\section{Introduction}

The endosomal system is comprised of an interconnected set of organelles whose principal functions are nutrient acquisition, the control of protein and lipid turnover, protection from pathogens, and to serve as a reservoir of membrane to support rapid changes in the surface area of the plasma membrane. The proteins and lipids that constitute the organelles of the endosomal system are derived principally by internalization of portions of the plasma membrane via multiple endocytic pathways. In addition, endosomes receive newly synthesized proteins, chiefly precursors of lysosomal acid hydrolases and other lysosomal residents from the secretory pathway via vesicular trafficking from the Golgi apparatus. Primary endocytic vesicles can undergo homotypic fusion to generate an 'early,' sometimes called 'sorting,' endosome de novo, or fuse with an existing early endosome. A maturation pathway converts an early endosome into a late endosome by gradually acidifying the fluid within the endosome lumen, which promotes the dissociation of internalized ligands such as nutrients and growth factors from their receptors, and molecular sorting reactions that either serve to target molecules into the lysosomal degradation pathway, or export proteins from the endosome and deliver them to other organelles for re-use (Fig. 1). Export of proteins and

\footnotetext{
Christopher G. Burd ; Email: christopher.burd@yale.edu

${ }^{2}$ Present Address: Department of Biological Sciences, University of North Carolina at Charlotte, Charlotte, NC 28223, USA
} 
lipids occurs via recycling and retrograde pathways, and is mediated by vesicular and tubular transport carriers that bud and fission from the endosome and then ferry their contents to its destination; 'recycling' pathways convey molecules, chiefly signaling receptors, nutrient and ion transporters, from the endosome to the plasma membrane, and 'retrograde' pathways transport molecules, chiefly sorting receptors, proteases, and SNARE molecules, from the endosome-to-the Golgi apparatus. We term the organelles that are derived from an endosome and mediate trafficking to other organelles within the cell, 'endosome-derived transport carriers' (ETCs).

The morphologic features of endosomes are a key for understanding the molecular sorting reactions that take place within the endosome membrane $\left[{ }^{1}\right]$. Three types of topological features characterize the membranes of the endosomal system (Fig. 1): a spherical vacuolar domain that is characterized by a small relative surface area-to-volume ratio, a tubular domain that originates from the vacuolar domain and which possesses a relatively large membrane surface area and small luminal volume, and vesicles within the lumen of the endosome (intra-luminal vesicles; ILVs) that are enriched in molecules that are earmarked for degradation via the lysosomal turnover pathway. Whereas early endosomes are distinguished from late endosomes by the presence of tubules that bud from a vacuolar domain whose lumen is modestly acidic ( $\mathrm{pH} \sim 6.5$ ) and contains few ILVs, late endosomes possess an acidic ( $\mathrm{pH} \sim 5.5$ ) lumen containing many intra-luminal vesicles, and are also called 'multi-vesicular bodies' (MVBs). The proteins that mediate MVB sorting and intraluminal vesicle formation constitute several complexes, termed endosomal sorting complexes required for transport (ESCRT), and a mechanism of ILV biogenesis is beginning to emerge $\left[{ }^{2}\right]$. By contrast, the machineries and mechanisms that mediate the sorting and export of cargo via recycling and retrograde trafficking pathways are far less well understood. Fortunately, in recent years, there has been significant progress towards identifying components of these pathways required for cargo sorting and packaging into budding ETCs, and how they are released from the 'mother' endosome. An emergent theme of this progress is the key roles that members of the sorting nexin protein family play in each stage of ETC formation. Here, we highlight and summarize these recent advances.

\section{Roles for sorting nexins in cargo export from the endosome}

The formation of an ETC involves packaging of lipids and select proteins into a vesicle or tubule that buds from and undergoes scission from the mother endosome. In the canonical paradigm of vesicle-mediated inter-organelle trafficking, the transport vesicle that buds from a donor organelle is enveloped by an oligomeric protein complex, such as clathrin or coatomer and their associated cofactors (e.g., cargo adapters), that mediates the selection of cargo and promotes membrane deformation required for budding. With this perspective in mind, the field has focused on identifying oligomeric coat proteins that might provide similar functions at the endosome. However, due to the complexities of the trafficking pathways that originate from the endosome, the ephemeral nature of maturing the endosome, and the diverse shapes and properties of membranes within the endosomal system, the classical vesicle biogenesis paradigm may not strictly apply at the endosome. For example, whereas the well characterized vesicle coat proteins, coatomer-I, coatomer-II and clathrin (and associated cargo adapter proteins), recognize sorting signal motifs in cargo proteins and 
concentrate them into uniformly sized vesicles, ETCs vary substantially in morphology (spherical vesicles, and tubules of varying length, measuring up to several microns long), and tightly packed, regular membrane associated coats, akin to clathrin, have not been observed by electron microscopy on endosome-derived tubules. Nonetheless, there is a growing catalog of oligomeric proteins that are peripherally associated with endosome membranes and are required for sorting and transport of cargo; hence, these proteins are candidate ETC coat proteins. In particular, a subset of proteins of the sorting nexin (abbreviated SNX) family, defined by the presence of an evolutionarily related Phoxhomology (PX) domain that typically recognizes phosphatidylinositol 3-phosphate, a defining lipid of endosomal membranes, have emerged as key components of multiple endosome export pathways $\left[{ }^{3}\right]$.

\section{SNX-BAR proteins}

Sorting nexins are divided into sub-families (Fig. 2) based on the presence of other structural features within the protein $[3,4]$. One sub-family is defined by the presence of a dimeric membrane binding module, the Bin-Amphiphysin-Rvs (BAR) domain, which presents a curved, positively charged surface that binds avidly to membranes with high positive curvature. Whereas the PX domain confers specificity for the PtdIns $3 P$-containing endosome membrane, the BAR domain confers targeting to the tubular domain of the endosome. In vitro membrane binding and structural studies show that SNX-BAR proteins can oligomerize on a membrane surface via tip-to-tip interactions of the BAR domains $\left[{ }^{5}\right]$, thereby generating regular arrays that wrap a membrane tubule. When present in sufficient concentration, some SNX-BAR proteins can drive a topological transition of a spherical vacuole to a narrow, coated tubule, suggesting that oligomerization of these SNX-BARs on the membrane could aid in the formation of a tubular transport carrier $\left[{ }^{5}\right]$. These observations suggest that the vacuolar domain of the endosome $\left[{ }^{6}\right]$ provides a reservoir of SNX-BAR protomers that are recruited to the growing carrier tubule by oligomerization $\left[{ }^{7}\right]$, thereby promoting the growth of the budding tubule. Cataloging of human SNX-BARs on the basis of oligomerization, in vitro tubulation activity, and localization within cells suggests the potential for at least nine unique SNX-BAR coats to exist in cells (see $\left[{ }^{8},{ }^{9}\right]$ ). In principle, each potential SNX-BAR oligomer might confer a cargo-specific trafficking pathway, but the extent to which this is the case is yet to be determined.

\section{Retromer}

A subset of SNX-BAR proteins rely on a protein complex called 'retromer' that orchestrates the capture of cargo proteins with the recruitment of sorting nexins and other factors that regulate actin dynamics on the endosome membrane to promote the formation of multiple types of ETCs. Authoritative reviews on retromer have been published recently [10_12], so in this article, we shall only briefly describe the key features and functions of retromer as they relate to the biogenesis of ETCs.

Genetic studies of protein trafficking in the endo-lysosomal system of budding yeast (Saccharomyces cerevisiae) led to the discovery of retromer, which was originally defined as a stable complex of five proteins: a heterodimer of the Vps5 and Vps17 SNX-BAR proteins, 
and Vps26, Vps29, and Vps35 [ $\left.{ }^{13},{ }^{14}\right]$. The yeast retromer complex was found to be dissociated in high salt $(250 \mathrm{mM} \mathrm{NaCl})$ containing buffers into the Vps5-Vps17 SNX-BAR heterodimer and a Vps26-Vps29-Vps35 sub-complex [ $\left.{ }^{13}{ }^{14}\right]$, where Vps26 and Vps29 bind to opposite ends of Vps35 to form a 200 ̊ long flexible dumbbell shaped structure $\left[{ }^{15}{ }^{19}\right]$. The trimer sub-complex is often referred to as the cargo selective complex (abbreviated 'CSC') because it has been shown to recognize retrograde sorting signals in retrograde cargo proteins (Table 1). However, it is now recognized that other proteins that associate with retromer, including some sorting nexins, also recognize sorting signals, so it is misleading to simply refer to the Vps26-Vps29-Vps35 trimer in this manner. Moreover, whereas the number and amino acid sequences of retromer-associated sorting nexins vary considerably between evolutionarily divergent organisms, the Vps26, Vps29, Vps35 retromer subunits are remarkably well-conserved through eukaryotic evolution, indicating that the Vps26-Vps29-Vps35 trimer constitutes the functional core of retromer. Hence, in accordance with the suggestion of other researchers [10, 12 ], we will use 'retromer' to refer to the Vps26-Vps29-Vps35 trimer.

Retromer does not possess membrane binding activity and it therefore relies on endosome membrane via accessory factors, including sorting nexins, Rab GTPases and other proteins, to be recruited from the cytosol to the endosome membrane. This is best exemplified by yeast retromer, which is tightly associated with the Vps5-Vps17 SNX-BAR heterodimer and confers endosome localization $\left[{ }^{20}, 21\right]$. In a current model based on yeast retromer, one SNX-BAR dimer is associated along nearly its entire length with one retromer trimer, so that the an ETC retromer coat would be composed of alternating SNX-BAR-retromer subcomplexes $\left[^{17}\right]$. In this configuration, the retromer-SNX-BAR interface lies along the entire length of one side of each sub-complex, leaving one face of retromer and the SNXBAR available for binding cargo or other proteins. Unlike yeast retromer, however, the association of mammalian retromer with SNX-BARs is relatively weak, at least as assessed by co-immunopurification, and the extent to which this reflects structural and functional differences between yeast and human retromer complexes remains unclear [ $\left.{ }^{22}, 23\right]$.

Moreover, in vertebrates, the SNX-BAR proteins that associate with retromer have expanded to include Snx1, Snx2, Snx5, Snx6, which form heterodimers [ ${ }^{14},{ }^{24}{ }^{26}$ ] (Fig. 2a, b). It is possible that the diversification of human SNX-BAR proteins that function on retromerdependent pathways reflects the increased diversity of cargo proteins in trafficking itineraries in metazoans cells compared to yeast cells, which is accommodated by decreased stability of the SNX-BAR-retromer holo-complex. In addition to sorting nexins, Rab7 family GTPases also confers membrane association of retromer by directly binding to the Vps 35 subunit [21, 27_29].

In vertebrate cells, branched filamentous actin (F-actin) is associated with sub-domains of the endosome membrane where retromer is also localized [ $\left.{ }^{30}{ }^{32}\right]$. Retromer plays a direct role in directing actin polymerization at the endosome membrane by recruiting 'WASH,' a complex of five proteins (WASH1, strumpellin, SWIP, FAM21 and CCDC53) that activates the ARP2/3 actin nucleation promoting factor [ $30,33,34$ ]. In murine WASH1 knockout cells, the endo-lysosomal system collapses into several large, aberrant organelles that contain endocytic cargos and lysosomal proteins [ 35 -37], indicating that WASH-mediated actin dynamics plays a profound role in the structure and function of endo-lysosomal 
system, though the specific molecular events that are regulated by WASH-mediated actin dynamics remain to be defined. Branched actin filaments have been observed to be associated with tubular domains of the endosome that contain cargo that is sorted by retromer $\left[{ }^{38}\right.$ ] and mutations that ablate WASH-retromer binding result in a failure of retromer-mediated cargo sorting $[35,36,38,39]$. These observations have led to the suggestion that a network of F-actin restricts the diffusion of retromer-associated cargo proteins within a patch in the membrane facilitating their incorporation into a budding ETC $\left[{ }^{10}\right]$, akin to the role proposed for plasma membrane associated $\mathrm{F}$-actin in generating protein nanoclusters in the plasma membrane $\left[{ }^{40}\right]$. Evidence, discussed later in this review, suggests that WASH-mediated actin dynamics plays a role in ETC fission from the mother endosome.

\section{Retromer-independent SNX-BAR pathways}

The SNX4 SNX-BAR proteins localize to the early/sorting endosome, where in human cells, they function in retromer-independent plasma membrane recycling and endosome-to-Golgi retrograde trafficking pathways [ $\left.{ }^{41}{ }^{43}\right]$. In human cells, SNX4 proteins are required to export cargo, including the transferrin receptor (TfR) $\left[{ }^{42},{ }^{44}\right]$ and E-cadherin $\left[{ }^{45}\right]$, from peripheral early endosomes in tubules that are transported to the recycling endosome from where cargo is subsequently exported to the PM. Interestingly, SNX4 is the only SNX4family member than can tubulate membranes in vitro by forming stable homodimers and heterodimers with non-tubulating SNX-BARS SNX7 and SNX30 [ $\left.{ }^{5}\right]$. Therefore, SNX4 likely forms the functional core to the SNX4 family export pathways. SNX4 elicits transport of the ETC to the peri-nuclear region of the cell by binding KIBRA, a coactivator of the microtubule motor dynein $\left[{ }^{42}\right]$.

The yeast genome encodes three $\operatorname{Snx} 4$ family proteins, $\operatorname{Snx} 4$, Snx41, and $\operatorname{Snx} 42$, which form Snx4-Snx41 and Snx4-Snx42 heterodimers [ $\left.{ }^{41}\right]$. Whereas mutant cells lacking Snx4 or Snx42 fail to sort the Snc1 v-SNARE $\left[{ }^{41}\right]$ and the Can1 arginine transporter from the endosome-to-the Golgi [ $\left.{ }^{43}\right]$, deletion of Snx41 has no consequence on sorting of these cargos. Snc1 can be co-precipitated with $\mathrm{Snx} 4$ from cell lysates [ $\left.{ }^{41}\right]$ and results from large scale yeast two-hybrid interaction screening suggests that Snx4 may directly bind to Snc1, though this has yet to be established using purified proteins. The results suggest that the yeast Snx4 family proteins are components of two distinct trafficking pathways; a Snx4Snx42 heterodimer mediates retrograde trafficking of Snc1 and Can1, and a Snx4-Snx41 heterodimer whose functions have yet to be elucidated.

SNX-BAR proteins have roles in autophagy, a process that is induced by nutrient limitation whereby intracellular components—soluble proteins, mitochondria, other organelles-are packed within a double membrane vesicle that fuses with the lysosome, resulting in the degradation of its contents. The autophagosome membrane is decorated with a protein called LC3 (Atg8 in yeast) that is necessary for the biogenesis of the autophagosome. The SNXBAR protein, SNX18, is reported to bind LC3 and another autophagy protein, Atg16L, and siRNA knockdown of SNX18 results in a decrease in the number of autophagosomes that are produced when cells are starved. In nutrient replete cells, SNX18 localizes to the recycling endosome, suggesting that it may contribute to trafficking LC3 from the recycling endosome to the growing autophagosome, resulting in deficient autophagy [46_48]. 
Interestingly, membrane tubulation by SNX18 was shown to be regulated by phosphorylation of a residue located within the N-terminal amphipathic helix motif. Phosphorylation inhibits formation of autophagosomes suggesting that SNX18 phosphorylation controls its function in autophagy [ $\left.{ }^{46}\right]$.

Yeast cells lacking Snx4 or Snx42 are partially defective in the autophagy-related cytoplasm-to-vacuole pathway and in mitophagy (the turnover of mitochondria by autophagy), presumably due to mistrafficking of a protein(s) or lipid(s) required for these processes [49_52]. Unlike human cells that lack SNX18, localization of Atg8 (yeast LC3) does not appear to be affected in these mutant cells. Another candidate protein that may be trafficked by Snx4-Snx42 is Atg9, an integral membrane protein component of the autophagy machinery that localizes to Golgi and endosome compartments [ ${ }^{53}{ }^{55}$ ]. As an integral membrane protein, Atg9 may mark membrane that is used to grow the nascent autophagosome $\left[{ }^{55}\right]$. Accordingly, vesicles containing Atg9 are proposed to traffic Atg9 from the Golgi to the nascent autophagosome; in this model, endosome-to-Golgi trafficking of Atg9 by Snx4/Snx42 maintains a supply of Atg9 in the Golgi that sustains autophagosome biogenesis $\left[{ }^{56}\right]$. Snx4/Snx42 and retromer pathways, however, appear to be redundant with respect to endosome-to-Golgi trafficking of Atg9 [56, 57] indicating that Snx4-Snx42 must have an alternative or additional function in autophagy that remains to be elucidated.

\section{PX-only sorting nexins}

The "PX-only" subset of sorting nexins is composed of proteins that consist of a PX domain with minimal additional flanking sequences $\left[{ }^{58},{ }^{59}\right]$. The best characterized of these is SNX3, which was first recognized to have a role in endosomal sorting through genetic studies in yeast which indicated that it functions as a cargo-specific auxiliary subunit of retromer $\left[{ }^{60}\right]$. SNX12, which is very closely related to SNX3, has also been implicated in endosomal trafficking, possibly in association with retromer, though its contribution to retrograde transport is poorly understood [ $\left.{ }^{61}, 62\right]$. In metazoans, sorting of wntless (Wls), an integral membrane protein required for secretion of Wnt signaling proteins, was shown to be dependent on SNX3 and retromer, but is independent of SNX-BAR proteins [ $\left.63,{ }^{64}\right]$. At the time of this discovery, the identification of a SNX-BAR independent pathway undermined the assumption that retromer functions solely with SNX-BARs, and indicated that sorting nexins dictate sorting into distinct carriers/pathways. SNX3 directly binds VPS35 [ ${ }^{29}, 63$, 65,66 ] and the retromer cargos Wls and, in yeast, the iron permease complex, Fet3-Ftr1 $[60,64,67]$, supporting an active role for SNX3 in cargo selection. SNX3 binds with a high affinity to PtdIns3P-rich membranes regardless of curvature, possibly by virtue of the absence of other functional domains $\left[{ }^{63}, 68,69\right]$ and a looming question is how SNX3retromer transport carriers are formed without the membrane remodeling activity provided by SNX-BARs. One possibility is that recruitment of retromer to the endosome $\left[{ }^{29}, 63,70\right.$, ${ }^{71}$ ] may elicit local actin-dependent membrane remodeling via retromer-associated WASH complex. The roles of PX-only sorting nexins in endosomal sorting remain poorly understood and future studies will illuminate this piece of the endosomal sorting puzzle. 


\section{SNX-FERM sorting nexins}

Sorting nexins that contain a C-terminal FERM (band4.1/ezrin/radixin/moesin) domain (SNX17, SNX27, and SNX31) have recently received considerable attention due to their roles in plasma membrane recycling routes (Table 1; Figs. 1, 2d) [ $\left.{ }^{72}\right]$. The FERM domain is a protein interaction module that binds to proteins containing the sequence, Asn-Pro-X-Tyr (NPxY), which can function as a sorting signal in some integral membrane proteins, suggesting that SNX-FERM proteins function as adapters that select cargo for incorporation into an ETC. Loss of SNX-FERM function, either by RNAi-mediated depletion of the protein or by mutation of a sorting signal in a cargo protein, results in lysosome-mediated degradation of SNX-FERM cargo proteins, indicating that the core function of SNX-FERM proteins lies in export from a maturing endosome.

Plasma membrane recycling of integrins, P-selectin, APOER2, and low-density lipoprotein receptor-related protein 1 (LRP1) requires SNX17 [ ${ }^{73}{ }^{78}$ ] (Table 1). SNX17 is widely expressed and in polarized epithelial cells where it mediates export of cargo from the early endosome on tubular ETCs that ferry cargo to the basolateral sorting endosome, from where cargo is then subsequently trafficked to the basolateral membrane $\left[{ }^{75},{ }^{79}\right]$. In nonpolarized cells, it fulfills a similar function, in that it is required for trafficking of cargo from the early endosome to the recycling endosome $\left[73,77,80 \_83\right]$. SNX17 is observed to localize with the cargo on tubules that emanate from early endosomes $\left[{ }^{78}\right.$ ], however, it is yet unclear how these tubular ETCs are formed, as recycling of $\beta 1$ integrin is not affected by knockdown of retromer-associated sorting nexins (SNX1/2, SNX4, SNX5/6, SNX8, SNX27), retromer subunits, or WASH complex components $[77,84]$. Integrin recycling is ablated by RNAimediated knockdown of C-terminal Eps 15 homology domain (EHD) containing protein 3 (EHD3), a protein with endosomal membrane tubulation activity [ 85,86$]$. As discussed later in this article, EHD proteins constitute a second type of potential ETC coat proteins. Curiously, the highly related sorting nexin, SNX31, whose expression is restricted to urothelial cells of the bladder, has been implicated in lysosomal-mediated degradation of uroplakins [ ${ }^{87},{ }^{88}$ ].

In addition to a FERM domain, SNX27 also possesses a PDZ (PSD95, Dlg1, ZO-1) domain, which recognizes short amino acid motifs at the C-termini of target proteins $\left[{ }^{89}\right]$. Pioneering studies of SNX27 were carried out with neurons, where it was demonstrated to be required for recycling of the beta-2 adrenergic receptor ( $\beta 2 \mathrm{AR}$ ) $\left[{ }^{89}\right]$. However, SNX27 is widely expressed in mammalian tissues and silencing of SNX27 expression in retinal pigment epithelial cells results in lysosomal targeting and turnover of a large number $(>100)$ of plasma membrane proteins, including nutrient transporters and signaling receptors. An important clue to how SNX27 exerts its broad sorting function came from a proteomic study of SNX27 interacting proteins that led to the discovery that it binds directly to the VPS26 subunit of the retromer complex $\left[{ }^{84}\right]$. Through retromer interactions with SNX-BAR proteins and the WASH complex, SNX27 is proposed to direct cargo into SNX-BAR coated ETCs that return their cargo to the plasma membrane. The SNX27 recycling pathway can be considered to be a constitutive trafficking pathway that may be broadly integrated with neuron activity, metabolic homeostasis, and possibly other pathways [ $\left.{ }^{84},{ }^{89}\right]$. 


\section{Cargo recognition}

Cargos of retrograde and recycling pathways are integral membrane proteins that are packaged into tubular and vesicular transport carriers that bud and fission from the endosome (Table 1) $\left.{ }^{12}\right]$. Export prevents these proteins from being retained within the maturing endosome and incorporated into vesicles that bud into the interior of the endosome (intra-luminal vesicles; ILVs) and eventual degradation within the lysosome (Fig. 1). A longstanding assumption regarding export of cargo proteins from the endosomal system is that it would not require specific sorting machineries to select proteins for export because the large membrane surface area of the tubular endosomal network compared to the vacuolar domain of the endosome would be sufficient to segregate at least $99 \%$ of the integral membrane proteins in the endosome into the tubular network $\left[{ }^{90}\right]$. However, amino acid sequences of cargo proteins that function as recycling and retrograde sorting signals have been identified in numerous cargoes (Table 1) and complexes of peripheral oligomeric proteins that recognize sorting signals and coat the endosome membrane have been identified. It is now clear that both active, signal-dependent mechanisms and passive, bulk partitioning underlie cargo export from the endosome. Signal-dependent sorting reflects cargo-specific targeting to any of multiple destinations, and it provides mechanisms to control plasma membrane composition through changes in the efficiencies with which different proteins within an endosome are sorted into the recycling pathway.

Retromer is a major, perhaps the major, cargo recognition module of endosomal export pathways. All retromer cargo sorting signals identified so far lie within cytoplasmic domains of either type I integral membrane proteins or multi-pass transmembrane proteins (Table 1), and they generally contain hydrophobic and aromatic amino acids; examples include TrpLeu-Met (WLM) and Tyr-Leu-Leu (YLL) found in the cytoplasmic tails of cationindependent mannose 6-phosphate receptor (CI-MPR) and divalent metal transporter 1 isoform II (DMT1-II), respectively [91_93]. However, a predictive consensus motif for retromer recognition has not been firmly elucidated and recent evidence indicates that retromer may possess multiple cargo recognition sites, which may account for the diverse cargoes of retromer-mediated pathways. For example, the sorting signals of the yeast Vps10 sorting receptor and human DMT1-II iron transporter are recognized at a site near the Cterminus of VPS35 [ $\left.{ }^{29},{ }^{94}\right]$, but the Phe-Ala-Asn-Ser-His-Tyr sorting signal in human SorLA is recognized by VPS26 [ $\left.{ }^{91}\right]$. In addition, different regions of retromer may recognize distinct cargo motifs within a single cargo; the WLM motif in the CI-MPR tail is required for retromer-dependent sorting, but other regions of the CI-MPR tail also confer retromer binding $[92,95,96]$. Adding a layer of complexity to the regulation of cargo sorting, it has been shown that there are at least two paralogues of VPS26 (VPS26A and VPS26B) that assemble with VPS35 and VPS29 in mammalian cells. Interestingly, retromer formed between VPS26B, VPS35, and VPS29 is unable to interact with CI-MPR [ ${ }^{97}$ ]. As CI-MPR cargo is thought to be recognized by direct binding to VPS35 [ $\left[55,{ }^{98}\right]$, this finding highlights the intriguing possibility that retromer components play dynamic roles in regulating the function of retromer as a whole in cargo selection and sorting. Consistent with this idea, in vitro studies show that retromer is most efficiently recruited to liposomes when SNX3, RAB7, and a cargo tail (DMT1-II) are all present, suggesting the active participation 
of cargo in the process of retromer recruitment to the endosome membrane and ETC coat assembly [ $\left.{ }^{29}\right]$.

\section{ETC coat proteins and the cytoskeleton in ETC formation}

Early endosomes localize to the cell periphery, near the plasma membrane, and they are transported by microtubule-dependent motors as they mature to late endosomes, resulting in their accumulation near the peri-nuclear microtubule organizing center, where lysosomes also are enriched [ $\left.{ }^{99}\right]$. Microtubule minus end-directed movement (i.e., toward the microtubule organizing center) is mediated by the dynein motor complex, and is counteracted by plus end-directed movement on by kinesins (KIFs), such that the interplay between these motors underlies endosome positioning within the cell. In vitro studies show that KIFs can generate sufficient force to pull a tubules from a large, vacuolar liposome $\left[{ }^{100}\right]$, indicating that these motor molecules could, in principle, initiate budding, elongation and fission of a tubular transport carrier. Recent evidence indicates that a kinesin, KIF13A, localizes to the early endosome and maintains the peripheral position of the endosome within the cell $\left[{ }^{101}\right]$. Intriguingly, siRNA-mediated knockdown of KIF13A leads to a modest reduction in the rate of transferrin receptor recycling to the plasma membrane, and a decrease in the number of transferrin receptor containing tubules that emanate from the early endosome $\left[{ }^{101}\right]$. Conversely, overexpression of KIF13A led to an elaboration of the TEN associated with the early endosome, suggesting that KIF13A contributes to the generation of tubules loaded with transferrin receptor that presumably ferry the receptor to the cell surface $\left[{ }^{101}\right]$. Other KIFs, including KIF16B [ $\left.{ }^{102},{ }^{103}\right]$ and KIF3B [ $\left.{ }^{104}\right]$, are also required for recycling of plasma membrane proteins, however, these motors appear to be required for organelle transport rather than in budding and elongation of ETCs. The modest overall reduction in the rates of recycling of plasma membrane proteins in KIF siRNA cells, and the failure of microtubule disrupting agents to elicit collapse of the TEN [ $\left.{ }^{105}\right]$, suggests that microtubule-dependent motors are but one of several factors that contribute to the morphogenesis of tubular ETCs. Additional factors, perhaps SNX-BAR proteins, likely cooperate with microtubule-based motors to generate an ETC.

The membrane of the endosome is partitioned into distinct domains that constitute the functional units of the endosome with respect to the sorting of proteins into recycling/ retrograde pathways, the sites of formation of intraluminal vesicles containing cargo to be degraded, and the machineries that mediate fusion with other organelles (Figs. 1, 2). Oligomerization of SNX-BAR proteins is a likely mechanism whereby a domain of the endosome that mediates export of cargo from the endosome is established. In vitro studies of SNX-BAR oligomerization shows that it is sufficient to drive the transition from vacuolar to tubular morphology, however, these studies have employed nonphysiologic concentrations of SNX-BAR proteins, so it is presently unclear how, under physiological conditions, oligomerization of SNX-BAR proteins is coupled to the formation of an ETC [ $\left.{ }^{100}\right]$. Recent studies exploring the functional interplay between microtubule-based motors and SNX-BAR proteins provides some evidence that particular motors and sorting nexins cooperate to form sorting domains $\left[{ }^{44}, 101 \_104,106\right]$. Fluorescently tagged (i.e., ectopically expressed) SNX4 and the retromer SNX-BAR, SNX6, localize to distinct regions of an individual endosome $[42,106,107]$, and their $\left[{ }^{42}, 106,107\right]$ segregation was found to be perturbed in cells treated 
with siRNAs to particular motors $\left[{ }^{44}\right]$. Interestingly, SNX4 and SNX6 are reported to bind to components of the dynein/dynactin motor complex [ $\left.{ }^{42}, 106,107\right]$, raising the possibility that these interactions $\left[{ }^{44}\right]$ couple local, motor-dependent generation of positive membrane curvature and oligomerization of the SNX-BAR protein. One concern with this approach is that knockdown of motor molecules will have widespread effects that complicate the interpretation of these experiments. Going forward, it will be important to devise experimental strategies (e.g., point mutations) that selectively uncouple interactions between individual SNX-BAR proteins and their associated motor to elucidate the contributions of these interactions to endosome function.

\section{Fission mechanisms}

In the final step ETC biogenesis, fission of the ETC membrane releases it from its mother endosome. The mechanism(s) of endosome membrane fission is poorly understood, in part because of the diversity of ETC morphologies and the multiple types of proteins that coat ETCs. GTPases of the dynamin family are oligomeric mechanoenzymes that wrap around a membrane and promote fission by constriction of the dynamin ring. The best characterized of these enzymes is dynamin, which functions at the neck of clathrin coated endocytic vesicles, and there is no firm evidence that any dynamin family protein functions in an analogous manner at the endosome in mammalian cells. In yeast cells, however, the Vps1 dynamin family protein localizes prominently to endosomes that are decorated by retromer and SNX-BAR proteins, and retromer-mediated cargo export is deficient in cells lacking Vps1, implicating Vps1 as a core component of the yeast retromer pathway [ $\left.{ }^{6}\right]$. In cells lacking the SNX-BAR protein, Mvp1 (the yeast ortholog of human SNX8), endosome localization of $\mathrm{Vps} 1$ is substantially reduced, indicating that Mvp1 promotes targeting of Vps1 to the endosome [ $\left.{ }^{6}\right]$. Oligomerization of human dynamin on membrane tubules is strongly dependent on the diameter of tubule [ ${ }^{108}$ ], and it was suggested that Mvp1 promotes endosome targeting of $\mathrm{Vps} 1$ by generating constrictions on retromer-coated tubules that promote Vps1 oligomerization and ETC fission [ ${ }^{6}$ ] (Fig. 3c). These results, as well as studies of BAR domain proteins that function with dynamin in endocytosis [ ${ }^{109}$ ${ }^{111}$ ], underscore the intimate functional interplay between BAR domain containing proteins and dynamin-mediated fission machinery, and it is logical to expect that membrane scaffolding by SNX-BAR proteins in metazoan cells might similarly influence fission, although via mechanisms that do not require a dynamin family protein.

Mammalian cells express a family of proteins (EHD1-4) that possess a conserved ATPbinding domain that is related to the GTP-binding domain of dynamin, and a C-terminal Eps15 homology domain $(\mathrm{EH})\left[{ }^{112}, 113\right]$. The nucleotide binding domain displays a curved membrane binding surface and, like SNX-BAR proteins, EHD proteins can drive tubulation and vesiculation of liposomes via a scaffolding mechanism [112_114]. The EH domain binds Asn-Pro-Phe motifs [ $\left.{ }^{115},{ }^{116}\right]$ that are found in some Rab proteins, BAR domain proteins, and molecular motors [ ${ }^{117}$ ], suggesting that EHD proteins direct these factors to regions of the endosome membrane displaying positive curvature, such as a ETC tubule [112_114, 118_120]. A role for EHD proteins in fission of endosomal tubules is suggested by the observations that RNAi-mediated depletion of EHD1 (also known as RME-1) and EHD4 from cells results in an elaboration of tubules of the Endocytic Recycling 
Compartment (ERC), consistent with a physiological function for these proteins in ETC fission $\left[{ }^{114}\right]$. Further work is necessary to clarify whether or not EHD proteins promote fission under physiological conditions.

While mechanoenzymes such as dynamin elicit membrane fission by constricting the membrane, other fission mechanisms harness tensile forces arising from interactions between the endosome membrane and cytoskeletal elements. As introduced in the preceding section, microtubule- and actin-dependent motors provide force to deform the endosome membrane during ETC formation. Observation of endosomes in living cells reveals that some fission events are correlated with rapid bursts of endosome movement under the direction of dynein, suggesting that the tensile force exerted by microtubule-based motors is sufficient to elicit membrane fission $\left[{ }^{121}\right]$. Additional evidence in support of a microtubule motor-dependent fission mechanism comes from the discovery of a complex containing spastin, an ATP driven microtubule severing enzyme, and two proteins of the ESCRT endolysosomal degradative pathway complex, CHMP1B and IST1 [122_124]. These interactions are proposed to direct a local increase in microtubule plus ends on the vacuolar domain of the endosome where the ESCRT proteins are enriched, eliciting dynein-dependent traction and a consequent increase in tensile force leading to fission. Such a mechanism could direct fission at the junction between the vacuolar and tubular domains of the endosome (Fig. 3a).

The discovery of the endosome-associated WASH complex raised the possibility that actin dynamics might also be harnessed to elicit fission of ETCs. A precedent for a role of actin dynamics in membrane fission exists in yeast cells, where actin polymerization drives propulsion of clathrin coated endocytic vesicles into the cell, which is proposed to elicit fission [125_127]. Similarly, in cells that express the WASH complex, endosome-associated F-actin might be harnessed to propel the ETC away from the mother endosome, generating sufficient tensile force to elicit membrane fission (Fig. 3a). Alternatively, an actin network might 'cage' the endosome $\left[{ }^{121}\right]$, restricting its movement while a microtubule-based motor elongates the ETC, ultimately eliciting membrane fission (Fig. 3a).

Finally, it was recently reported that sites of contact between a tubule of the endoplasmic reticulum (ER) and the endosome precedes fission [ ${ }^{128}$ ] (Fig. 3b). Curiously, a similar event precedes mitochondrial fission $\left[{ }^{129}\right]$, but in neither case has the role of the contact site been elucidated. Clearly, the mechanisms of endosome fission represent an interesting and important area for which future research will be directed.

\section{Concluding remarks}

Sorting nexin proteins are key components of nearly every endosomal cargo's export. They function to capture cargo, either through direct recognition of sorting signals, or by recruiting the retromer complex to the endosome membrane. By promoting topological changes in membrane shape required to make ETCs, the SNX-BAR proteins act akin to the role of traditional vesicle coat proteins. A key difference, though, is that SNX-BAR proteins serve as a major interface between the endosome membrane and molecular motors whose actions contribute to cargo sorting, ETC budding and fission, and ETC transport to downstream organelles. An important emerging concept is that initial interactions between 
cargo, sorting nexins, and retromer seem to drive the formation of distinct ETCs, tailoring their biogenesis between vesicles, whose primary function lies in transport of particular proteins, and large tubules that carry bulk membrane and proteins. With the identification of sorting nexin roles in numerous trafficking pathways, and knowledge of the stages at which they operate, we anticipate that research in the near future will begin to elucidate the principles of cargo sorting and ETC assembly, and the manner in which ETCs are 'programmed' to be delivered to, and fuse with, downstream target organelles.

\section{Acknowledgments}

We are grateful to our colleagues for discussions and critical reading of the manuscript. This work was supported by grants from the United States National Institute of Health to C.G.B. (GM060221 and GM095766) and the Postdoctoral Fellowship from the American Heart Association to M.S.H. (13POST16930024).

\section{Abbreviations}

$\begin{array}{ll}\text { BAR } & \text { Bin-Amphiphysin-Rvs161 (BAR) homology } \\ \text { PX } & \text { Phox homology } \\ \text { SNX-BAR } & \text { Sorting nexin containing a BAR domain } \\ \text { TEN } & \text { Tubular endosomal network } \\ \text { WT } & \text { Wild-type }\end{array}$

\section{References}

1. Klumperman J, Raposo G. The complex ultrastructure of the endolysosomal system. Cold Spring Harb Perspect Biol. 2014; 6(10):a016857. doi:10.1101/cshperspect.a016857. [PubMed: 24851870]

2. Henne WM, Buchkovich NJ, Emr SD. The ESCRT pathway. Dev Cell. 2011; 21(1):77-91. doi: 10.1016/j.devcel.2011.05.015. [PubMed: 21763610]

3. Teasdale RD, Loci D, Houghton F, Karlsson L, Gleeson PA. A large family of endosome-localized proteins related to sorting nexin 1. Biochem J. 2001; 358(Pt 1):7-16. [PubMed: 11485546]

4. Gallon M, Cullen PJ. Retromer and sorting nexins in endosomal sorting. Biochem Soc Trans. 2015; 43(1):33-47. doi:10.1042/BST20140290. [PubMed: 25619244]

5. van Weering JR, Sessions RB, Traer CJ, Kloer DP, Bhatia VK, Stamou D, Carlsson SR, Hurley JH, Cullen PJ. Molecular basis for SNX-BAR-mediated assembly of distinct endosomal sorting tubules. EMBO J. 2012; 31(23):4466-4480. doi:10.1038/emboj.2012.283. [PubMed: 23085988]

6. Chi RJ, Liu J, West M, Wang J, Odorizzi G, Burd CG. Fission of SNX-BAR-coated endosomal retrograde transport carriers is promoted by the dynamin-related protein Vps1. J Cell Biol. 2014; 204(5):793-806. doi:10.1083/jcb.201309084. [PubMed: 24567361]

7. Simunovic M, Srivastava A, Voth GA. Linear aggregation of proteins on the membrane as a prelude to membrane remodeling. Proc Natl Acad Sci USA. 2013; 110(51):20396-20401. doi:10.1073/pnas. 1309819110. [PubMed: 24284177]

8. van Weering JR, Verkade P, Cullen PJ. SNX-BAR-mediated endosome tubulation is co-ordinated with endosome maturation. Traffic. 2012; 13(1):94-107. doi:10.1111/j.1600-0854.2011.01297.x. [PubMed: 21973056]

9. Sierecki E, Stevers LM, Giles N, Polinkovsky ME, Moustaqil M, Mureev S, Johnston WA, DahmerHeath M, Skalamera D, Gonda TJ, Gabrielli B, Collins BM, Alexandrov K, Gambin Y. Rapid mapping of interactions between Human SNX-BAR proteins measured in vitro by AlphaScreen and single-molecule spectroscopy. Mol Cell Proteomics. 2014; 13(9):2233-2245. doi:10.1074/ mcp.M113.037275. [PubMed: 24866125] 
10. Burd C, Cullen PJ. Retromer: a master conductor of endosome sorting. Cold Spring Harbor perspectives in biology. 2014; 6(2) doi:10.1101/cshperspect.a016774.

11. Cullen PJ, Korswagen HC. Sorting nexins provide diversity for retromer-dependent trafficking events. Nat Cell Biol. 2012; 14(1):29-37. doi:10.1038/ncb2374. [PubMed: 22193161]

12. Seaman MN. The retromer complex-endosomal protein recycling and beyond. J Cell Sci. 2012; 125(Pt 20):4693-4702. doi:10.1242/jcs.103440. [PubMed: 23148298]

13. Reddy JV, Seaman MN. Vps26p, a component of retromer, directs the interactions of Vps35p in endosome-to-Golgi retrieval. Mol Biol Cell. 2001; 12(10):3242-3256. [PubMed: 11598206]

14. Seaman MN, McCaffery JM, Emr SD. A membrane coat complex essential for endosome-to-Golgi retrograde transport in yeast. J Cell Biol. 1998; 142(3):665-681. [PubMed: 9700157]

15. Collins BM, Skinner CF, Watson PJ, Seaman MN, Owen DJ. Vps29 has a phosphoesterase fold that acts as a protein interaction scaffold for retromer assembly. Nat Struct Mol Biol. 2005; 12(7): 594-602. [PubMed: 15965486]

16. Collins BM, Norwood SJ, Kerr MC, Mahony D, Seaman MN, Teasdale RD, Owen DJ. Structure of Vps26B and mapping of its interaction with the retromer protein complex. Traffic. 2008; 9(3):366379. [PubMed: 18088321]

17. Hierro A, Rojas AL, Rojas R, Murthy N, Effantin G, Kajava AV, Steven AC, Bonifacino JS, Hurley JH. Functional architecture of the retromer cargo-recognition complex. Nature. 2007; 449(7165): 1063-1067. [PubMed: 17891154]

18. Miller SE, Collins BM, McCoy AJ, Robinson MS, Owen DJ. A SNARE-adaptor interaction is a new mode of cargo recognition in clathrin-coated vesicles. Nature. 2007; 450(7169):570-574. doi: 10.1038/nature06353. [PubMed: 18033301]

19. Norwood SJ, Shaw DJ, Cowieson NP, Owen DJ, Teasdale RD, Collins BM. Assembly and solution structure of the core retromer protein complex. Traffic. 2010 doi:10.1111/j. 1600-0854.2010.01124.x.

20. Horazdovsky BF, Davies BA, Seaman MN, McLaughlin SA, Yoon S, Emr SD. A sorting nexin-1 homologue, Vps5p, forms a complex with Vps17p and is required for recycling the vacuolar protein-sorting receptor. Mol Biol Cell. 1997; 8(8):1529-1541. [PubMed: 9285823]

21. Liu TT, Gomez TS, Sackey BK, Billadeau DD, Burd CG. Rab GTPase regulation of retromermediated cargo export during endosome maturation. Mol Biol Cell. 2012; 23(13):2505-2515. doi: 10.1091/mbc.E11-11-0915. [PubMed: 22593205]

22. Rojas R, Kametaka S, Haft CR, Bonifacino JS. Interchangeable but essential functions of SNX1 and SNX2 in the association of retromer with endosomes and the trafficking of mannose 6phosphate receptors. Mol Cell Biol. 2007; 27(3):1112-1124. [PubMed: 17101778]

23. Wassmer T, Attar N, Bujny MV, Oakley J, Traer CJ, Cullen PJ. A loss-of-function screen reveals SNX5 and SNX6 as potential components of the mammalian retromer. J Cell Sci. 2007; 120(Pt 1): 45-54. [PubMed: 17148574]

24. Koumandou VL, Klute MJ, Herman EK, Nunez-Miguel R, Dacks JB, Field MC. Evolutionary reconstruction of the retromer complex and its function in Trypanosoma brucei. J Cell Sci. 2011; 124(Pt 9):1496-1509. doi:10.1242/jcs.081596. [PubMed: 21502137]

25. Seaman MN, Marcusson EG, Cereghino JL, Emr SD. Endosome to Golgi retrieval of the vacuolar protein sorting receptor, Vps10p, requires the function of the VPS29, VPS30, and VPS35 gene products (in process citation). J Cell Biol. 1997; 137(1):79-92. [PubMed: 9105038]

26. Wassmer T, Attar N, Harterink M, van Weering JR, Traer CJ, Oakley J, Goud B, Stephens DJ, Verkade P, Korswagen HC, Cullen PJ. The retromer coat complex coordinates endosomal sorting and dynein-mediated transport, with carrier recognition by the trans-Golgi network. Dev Cell. 2009; 17(1):110-122. doi:10.1016/j.devcel.2009.04.016. [PubMed: 19619496]

27. Rojas R, van Vlijmen T, Mardones GA, Prabhu Y, Rojas AL, Mohammed S, Heck AJ, Raposo G, van der Sluijs P, Bonifacino JS. Regulation of retromer recruitment to endosomes by sequential action of Rab5 and Rab7. J Cell Biol. 2008; 183(3):513-526. doi:10.1083/jcb.200804048. [PubMed: 18981234]

28. Seaman MN, Harbour ME, Tattersall D, Read E, Bright N. Membrane recruitment of the cargoselective retromer subcomplex is catalysed by the small GTPase Rab7 and inhibited by the Rab- 
GAP TBC1D5. J Cell Sci. 2009; 122(Pt 14):2371-2382. doi:10.1242/jcs.048686. [PubMed: 19531583]

29. Harrison MS, Hung CS, Liu TT, Christiano R, Walther TC, Burd CG. A mechanism for retromer endosomal coat complex assembly with cargo. Proc Natl Acad Sci USA. 2014; 111(1):267-272. doi:10.1073/pnas.1316482111. [PubMed: 24344282]

30. Linardopoulou EV, Parghi SS, Friedman C, Osborn GE, Parkhurst SM, Trask BJ. Human subtelomeric WASH genes encode a new subclass of the WASP family. PLoS Genet. 2007; 3(12):e237. doi:10.1371/journal.pgen.0030237. [PubMed: 18159949]

31. Gomez TS, Billadeau DD. A FAM21-containing WASH complex regulates retromer-dependent sorting. Dev Cell. 2009; 17(5):699-711. doi:10.1016/j.devcel.2009.09.009. [PubMed: 19922874]

32. Derivery E, Sousa C, Gautier JJ, Lombard B, Loew D, Gautreau A. The Arp2/3 activator WASH controls the fission of endosomes through a large multiprotein complex. Dev Cell. 2009; 17(5): 712-723. doi:10.1016/j.devcel.2009.09.010. [PubMed: 19922875]

33. Carnell M, Zech T, Calaminus SD, Ura S, Hagedorn M, Johnston SA, May RC, Soldati T, Machesky LM, Insall RH. Actin polymerization driven by WASH causes V-ATPase retrieval and vesicle neutralization before exocytosis. J Cell Biol. 2011; 193(5):831-839. doi:10.1083/jcb. 201009119. [PubMed: 21606208]

34. Seaman MN, Gautreau A, Billadeau DD. Retromer-mediated endosomal protein sorting: all WASHed up! Trends Cell Biol. 2013; 23(11):522-528. doi:10.1016/j.tcb.2013.04.010. [PubMed: 23721880]

35. Derivery E, Helfer E, Henriot V, Gautreau A. Actin polymerization controls the organization of WASH domains at the surface of endosomes. PLoS ONE. 2012; 7(6):e39774. doi:10.1371/ journal.pone.0039774. [PubMed: 22737254]

36. Duleh SN, Welch MD. WASH and the Arp2/3 complex regulate endosome shape and trafficking. Cytoskeleton. 2010; 67(3):193-206. doi:10.1002/cm.20437. [PubMed: 20175130]

37. Gomez TS, Gorman JA, de Narvajas AA, Koenig AO, Billadeau DD. Trafficking defects in WASH-knockout fibroblasts originate from collapsed endosomal and lysosomal networks. Mol Biol Cell. 2012; 23(16):3215-3228. doi:10.1091/mbc.E12-02-0101. [PubMed: 22718907]

38. Puthenveedu MA, Lauffer B, Temkin P, Vistein R, Carlton P, Thorn K, Taunton J, Weiner OD, Parton RG, von Zastrow M. Sequence-dependent sorting of recycling proteins by actin-stabilized endosomal microdomains. Cell. 2010; 143(5):761-773. doi:10.1016/j.cell.2010.10.003. [PubMed: 21111236]

39. Jia D, Gomez TS, Billadeau DD, Rosen MK. Multiple repeat elements within the FAM21 tail link the WASH actin regulatory complex to the retromer. Mol Biol Cell. 2012; 23(12):2352-2361. doi: 10.1091/mbc.E11-12-1059. [PubMed: 22513087]

40. Rao M, Mayor S. Active organization of membrane constituents in living cells. Curr Opin Cell Biol. 2014; 29:126-132. doi:10.1016/j.ceb.2014.05.007. [PubMed: 24975942]

41. Hettema EH, Lewis MJ, Black MW, Pelham HR. Retromer and the sorting nexins Snx4/41/42 mediate distinct retrieval pathways from yeast endosomes. EMBO J. 2003; 22(3):548-557. [PubMed: 12554655]

42. Traer CJ, Rutherford AC, Palmer KJ, Wassmer T, Oakley J, Attar N, Carlton JG, Kremerskothen J, Stephens DJ, Cullen PJ. SNX4 coordinates endosomal sorting of TfnR with dynein-mediated transport into the endocytic recycling compartment. Nat Cell Biol. 2007; 9(12):1370-1380. [PubMed: 17994011]

43. Shi Y, Stefan CJ, Rue SM, Teis D, Emr SD. Two novel WD40 domain-containing proteins, Ere1 and Ere2, function in the retromer-mediated endosomal recycling pathway. Mol Biol Cell. 2011; 22(21):4093-4107. doi:10.1091/mbc.E11-05-0440. [PubMed: 21880895]

44. Hunt SD, Townley AK, Danson CM, Cullen PJ, Stephens DJ. Microtubule motors mediate endosomal sorting by maintaining functional domain organization. J Cell Sci. 2013 doi:10.1242/ jes.122317.

45. Solis GP, Hulsbusch N, Radon Y, Katanaev VL, Plattner H, Stuermer CA. Reggies/flotillins interact with Rab11a and SNX4 at the tubulovesicular recycling compartment and function in transferrin receptor and E-cadherin trafficking. Mol Biol Cell. 2013; 24(17):2689-2702. doi: 10.1091/mbc.E12-12-0854. [PubMed: 23825023] 
46. Knaevelsrud H, Carlsson SR, Simonsen A. SNX18 tubulates recycling endosomes for autophagosome biogenesis. Autophagy. 2013; 9(10):1639-1641. doi:10.4161/auto.26124. [PubMed: 24113029]

47. Haberg K, Lundmark R, Carlsson SR. SNX18 is an SNX9 paralog that acts as a membrane tubulator in AP-1-positive endosomal trafficking. J Cell Sci. 2008; 121(Pt 9):1495-1505. doi: 10.1242/jcs.028530. [PubMed: 18411244]

48. Park J, Kim Y, Lee S, Park JJ, Park ZY, Sun W, Kim H, Chang S. SNX18 shares a redundant role with SNX9 and modulates endocytic trafficking at the plasma membrane. J Cell Sci. 2010; 123(Pt 10):1742-1750. doi:10.1242/jcs.064170. [PubMed: 20427313]

49. Kanki T, Wang K, Baba M, Bartholomew CR, Lynch-Day MA, Du Z, Geng J, Mao K, Yang Z, Yen WL, Klionsky DJ. A genomic screen for yeast mutants defective in selective mitochondria autophagy. Mol Biol Cell. 2009; 20(22):4730-4738. doi:10.1091/mbc.E09-03-0225. [PubMed: 19793921]

50. Mendl N, Occhipinti A, Muller M, Wild P, Dikic I, Reichert AS. Mitophagy in yeast is independent of mitochondrial fission and requires the stress response gene WHI2. J Cell Sci. 2011; 124(Pt 8): 1339-1350. doi:10.1242/jcs.076406. [PubMed: 21429936]

51. Nice DC, Sato TK, Stromhaug PE, Emr SD, Klionsky DJ. Cooperative binding of the cytoplasm to vacuole targeting pathway proteins, Cvt13 and Cvt20, to phosphatidylinositol 3-phosphate at the pre-autophagosomal structure is required for selective autophagy. J Biol Chem. 2002; 277(33): 30198-30207. doi:10.1074/jbc.M204736200. [PubMed: 12048214]

52. Okamoto K, Kondo-Okamoto N, Ohsumi Y. Mitochondria-anchored receptor Atg32 mediates degradation of mitochondria via selective autophagy. Dev Cell. 2009; 17(1):87-97. doi:10.1016/ j.devcel.2009.06.013. [PubMed: 19619494]

53. Mari M, Griffith J, Rieter E, Krishnappa L, Klionsky DJ, Reggiori F. An Atg9-containing compartment that functions in the early steps of autophagosome biogenesis. J Cell Biol. 2010; 190(6):1005-1022. doi:10.1083/jcb.200912089. [PubMed: 20855505]

54. Webber JL, Tooze SA. New insights into the function of Atg9. FEBS Lett. 2010; 584(7):13191326. doi:10.1016/j.febslet.2010.01.020. [PubMed: 20083107]

55. Yamamoto H, Kakuta S, Watanabe TM, Kitamura A, Sekito T, Kondo-Kakuta C, Ichikawa R, Kinjo M, Ohsumi Y. Atg9 vesicles are an important membrane source during early steps of autophagosome formation. J Cell Biol. 2012; 198(2):219-233. doi:10.1083/jcb.201202061. [PubMed: 22826123]

56. Shirahama-Noda K, Kira S, Yoshimori T, Noda T. TRAPPIII is responsible for vesicular transport from early endosomes to Golgi, facilitating Atg9 cycling in autophagy. J Cell Sci. 2013; 126(Pt 21):4963-4973. doi:10.1242/jcs.131318. [PubMed: 23986483]

57. Ohashi Y, Munro S. Membrane delivery to the yeast autophagosome from the Golgi-endosomal system. Mol Biol Cell. 2010; 21(22):3998-4008. doi:10.1091/mbc.E10-05-0457. [PubMed: 20861302]

58. Seet LF, Hong W. The Phox (PX) domain proteins and membrane traffic. Biochim Biophys Acta. 2006; 1761(8):878-896. [PubMed: 16782399]

59. Teasdale RD, Collins BM. Insights into the PX (phoxhomology) domain and SNX (sorting nexin) protein families: structures, functions and roles in disease. Biochem J. 2012; 441(1):39-59. doi: 10.1042/BJ20111226. [PubMed: 22168438]

60. Strochlic TI, Setty TG, Sitaram A, Burd CG. Grd19/Snx3p functions as a cargo-specific adapter for retromer-dependent endocytic recycling. J Cell Biol. 2007; 177(1):115-125. [PubMed: 17420293]

61. Pons V, Luyet PP, Morel E, Abrami L, van der Goot FG, Parton RG, Gruenberg J. Hrs and SNX3 functions in sorting and membrane invagination within multivesicular bodies. PLoS Biol. 2008; 6(9):e214. doi:10.1371/journal.pbio.0060214. [PubMed: 18767904]

62. Zhao Y, Wang Y, Yang J, Wang X, Zhao Y, Zhang X, Zhang YW. Sorting nexin 12 interacts with BACE1 and regulates BACE1-mediated APP processing. Mol Neurodegener. 2012; 7:30. doi: 10.1186/1750-1326-7-30. [PubMed: 22709416]

63. Harterink M, Port F, Lorenowicz MJ, McGough IJ, Silhankova M, Betist MC, van Weering JR, van Heesbeen RG, Middelkoop TC, Basler K, Cullen PJ, Korswagen HC. A SNX3-dependent retromer 
pathway mediates retrograde transport of the Wnt sorting receptor Wntless and is required for Wnt secretion. Nat Cell Biol. 2011; 13(8):914-923. doi:10.1038/ncb2281. [PubMed: 21725319]

64. Zhang P, Wu Y, Belenkaya TY, Lin X. SNX3 controls Wingless/Wnt secretion through regulating retromer-dependent recycling of Wntless. Cell Res. 2011; 21(12):1677-1690. doi:10.1038/cr. 2011.167. [PubMed: 22041890]

65. Restrepo R, Zhao X, Peter H, Zhang BY, Arvan P, Nothwehr SF. Structural features of vps35p involved in interaction with other subunits of the retromer complex. Traffic. 2007; 8(12):18411853. [PubMed: 17892535]

66. Strochlic TI, Schmiedekamp BC, Lee J, Katzmann DJ, Burd CG. Opposing activities of the Snx3retromer complex and ESCRT proteins mediate regulated cargo sorting at a common endosome. Mol Biol Cell. 2008; 19(11):4694-4706. doi:10.1091/mbc.E08-03-0296. [PubMed: 18768754]

67. Zhang L, Lee SY, Beznoussenko GV, Peters PJ, Yang JS, Gilbert HY, Brass AL, Elledge SJ, Isaacs SN, Moss B, Mironov A, Hsu VW. A role for the host coatomer and KDEL receptor in early vaccinia biogenesis. Proc Natl Acad Sci USA. 2009; 106(1):163-168. doi:10.1073/pnas. 0811631106. [PubMed: 19109439]

68. Cozier GE, Carlton J, McGregor AH, Gleeson PA, Teasdale RD, Mellor H, Cullen PJ. The phox homology (PX) domain-dependent, 3-phosphoinositide-mediated association of sorting nexin-1 with an early sorting endosomal compartment is required for its ability to regulate epidermal growth factor receptor degradation. J Biol Chem. 2002; 277(50):48730-48736. [PubMed: 12198132]

69. Yu JW, Lemmon MA. All phox homology (PX) domains from Saccharomyces cerevisiae specifically recognize phosphatidylinositol 3-phosphate. J Biol Chem. 2001; 276(47):4417944184. [PubMed: 11557775]

70. Harbour ME, Breusegem SY, Seaman MN. Recruitment of the endosomal WASH complex is mediated by the extended 'tail' of Fam 21 binding to the retromer protein Vps35. Biochem J. 2012; 442(1):209-220. doi:10.1042/BJ20111761. [PubMed: 22070227]

71. Vardarajan BN, Bruesegem SY, Harbour ME, St George-Hyslop P, Seaman MN, Farrer LA. Identification of Alzheimer disease-associated variants in genes that regulate retromer function. Neurobiol Aging. 2012; 33(9):2231.e2215-2231.e2230. doi:10.1016/j.neurobiolaging. 2012.04.020. [PubMed: 22673115]

72. Ghai R, Bugarcic A, Liu H, Norwood SJ, Skeldal S, Coulson EJ, Li SS, Teasdale RD, Collins BM. Structural basis for endosomal trafficking of diverse transmembrane cargos by PX-FERM proteins. Proc Natl Acad Sci USA. 2013; 110(8):E643-E652. doi:10.1073/pnas.1216229110. [PubMed: 23382219]

73. Knauth P, Schluter T, Czubayko M, Kirsch C, Florian V, Schreckenberger S, Hahn H, Bohnensack R. Functions of sorting nexin 17 domains and recognition motif for P-selectin trafficking. J Mol Biol. 2005; 347(4):813-825. doi:10.1016/j.jmb.2005.02.004. [PubMed: 15769472]

74. Bottcher RT, Stremmel C, Meves A, Meyer H, Widmaier M, Tseng HY, Fassler R. Sorting nexin 17 prevents lysosomal degradation of betal integrins by binding to the beta1-integrin tail. Nat Cell Biol. 2012; 14(6):584-592. doi:10.1038/ncb2501. [PubMed: 22561348]

75. Farfan P, Lee J, Larios J, Sotelo P, Bu G, Marzolo MP. A sorting nexin 17-binding domain within the LRP1 cytoplasmic tail mediates receptor recycling through the basolateral sorting endosome. Traffic. 2013; 14(7):823-838. doi:10.1111/tra.12076. [PubMed: 23593972]

76. Sotelo P, Farfan P, Benitez ML, Bu G, Marzolo MP. Sorting nexin 17 regulates ApoER2 recycling and reelin signaling. PLoS ONE. 2014; 9(4):e93672. doi:10.1371/journal.pone.0093672. [PubMed: 24705369]

77. Steinberg F, Heesom KJ, Bass MD, Cullen PJ. SNX17 protects integrins from degradation by sorting between lysosomal and recycling pathways. J Cell Biol. 2012; 197(2):219-230. doi: 10.1083/jcb.201111121. [PubMed: 22492727]

78. van Kerkhof P, Lee J, McCormick L, Tetrault E, Lu W, Schoenfish M, Oorschot V, Strous GJ, Klumperman J, Bu G. Sorting nexin 17 facilitates LRP recycling in the early endosome. EMBO J. 2005; 24(16):2851-2861. doi:10.1038/sj.emboj.7600756. [PubMed: 16052210]

79. Donoso M, Cancino J, Lee J, van Kerkhof P, Retamal C, Bu G, Gonzalez A, Caceres A, Marzolo MP. Polarized traffic of LRP1 involves AP1B and SNX17 operating on Y-dependent sorting motifs 
in different pathways. Mol Biol Cell. 2009; 20(1):481-497. doi:10.1091/mbc.E08-08-0805. [PubMed: 19005208]

80. Burden JJ, Sun XM, Garcia AB, Soutar AK. Sorting motifs in the intracellular domain of the low density lipoprotein receptor interact with a novel domain of sorting nexin-17. J Biol Chem. 2004; 279(16):16237-16245. doi:10.1074/jbc.M313689200. [PubMed: 14739284]

81. Lee J, Retamal C, Cuitino L, Caruano-Yzermans A, Shin JE, van Kerkhof P, Marzolo MP, Bu G. Adaptor protein sorting nexin 17 regulates amyloid precursor protein trafficking and processing in the early endosomes. J Biol Chem. 2008; 283(17):11501-11508. doi:10.1074/jbc.M800642200. [PubMed: 18276590]

82. Stockinger W, Sailler B, Strasser V, Recheis B, Fasching D, Kahr L, Schneider WJ, Nimpf J. The PX-domain protein SNX17 interacts with members of the LDL receptor family and modulates endocytosis of the LDL receptor. EMBO J. 2002; 21(16):4259-4267. [PubMed: 12169628]

83. Williams R, Schluter T, Roberts MS, Knauth P, Bohnensack R, Cutler DF. Sorting nexin 17 accelerates internalization yet retards degradation of P-selectin. Mol Biol Cell. 2004; 15(7):30953105. doi:10.1091/mbc.E04-02-0143. [PubMed: 15121882]

84. Steinberg F, Gallon M, Winfield M, Thomas EC, Bell AJ, Heesom KJ, Tavare JM, Cullen PJ. A global analysis of SNX27-retromer assembly and cargo specificity reveals a function in glucose and metal ion transport. Nat Cell Biol. 2013 doi:10.1038/ncb2721.

85. Cai B, Giridharan SS, Zhang J, Saxena S, Bahl K, Schmidt JA, Sorgen PL, Guo W, Naslavsky N, Caplan S. Differential roles of C-terminal Eps15 homology domain proteins as vesiculators and tubulators of recycling endosomes. J Biol Chem. 2013; 288(42):30172-30180. doi:10.1074/ jbc.M113.488627. [PubMed: 24019528]

86. Waxmonsky NC, Conner SD. Alphavbeta3-integrin-mediated adhesion is regulated through an AAK1L- and EHD3-dependent rapid-recycling pathway. J Cell Sci. 2013; 126(Pt 16):3593-3601. doi:10.1242/jcs.122465. [PubMed: 23781025]

87. Tseng HY, Thorausch N, Ziegler T, Meves A, Fassler R, Bottcher RT. Sorting nexin 31 binds multiple beta integrin cytoplasmic domains and regulates beta1 integrin surface levels and stability. J Mol Biol. 2014; 426(18):3180-3194. doi:10.1016/j.jmb.2014.07.003. [PubMed: 25020227]

88. Vieira N, Deng FM, Liang FX, Liao Y, Chang J, Zhou G, Zheng W, Simon JP, Ding M, Wu XR, Romih R, Kreibich G, Sun TT. SNX31: a novel sorting nexin associated with the uroplakindegrading multivesicular bodies in terminally differentiated urothelial cells. PLoS ONE. 2014; 9(6):e99644. doi:10.1371/journal.pone.0099644. [PubMed: 24914955]

89. Temkin P, Lauffer B, Jager S, Cimermancic P, Krogan NJ, von Zastrow M. SNX27 mediates retromer tubule entry and endosome-to-plasma membrane trafficking of signalling receptors. Nat Cell Biol. 2011; 13(6):715-721. doi:10.1038/ncb2252. [PubMed: 21602791]

90. Maxfield FR, McGraw TE. Endocytic recycling. Nat Rev Mol Cell Biol. 2004; 5(2):121-132. [PubMed: 15040445]

91. Fjorback AW, Seaman M, Gustafsen C, Mehmedbasic A, Gokool S, Wu C, Militz D, Schmidt V, Madsen P, Nyengaard JR, Willnow TE, Christensen EI, Mobley WB, Nykjaer A, Andersen OM. Retromer binds the FANSHY sorting motif in SorLA to regulate amyloid precursor protein sorting and processing. J Neurosci. 2012; 32(4):1467-1480. doi:10.1523/JNEUROSCI.2272-11.2012. [PubMed: 22279231]

92. Seaman MN. Identification of a novel conserved sorting motif required for retromer-mediated endosome-to-TGN retrieval. J Cell Sci. 2007; 120(Pt 14):2378-2389. [PubMed: 17606993]

93. Tabuchi M, Yanatori I, Kawai Y, Kishi F. Retromer-mediated direct sorting is required for proper endosomal recycling of the mammalian iron transporter DMT1. J Cell Sci. 2010; 123(Pt 5):756766. doi:10.1242/jcs.060574. [PubMed: 20164305]

94. Nothwehr SF, Bruinsma P, Strawn LA. Distinct domains within Vps35p mediate the retrieval of two different cargo proteins from the yeast prevacuolar/endosomal compartment. Mol Biol Cell. 1999; 10(4):875-890. [PubMed: 10198044]

95. Arighi CN, Hartnell LM, Aguilar RC, Haft CR, Bonifacino JS. Role of the mammalian retromer in sorting of the cation-independent mannose 6-phosphate receptor. J Cell Biol. 2004; 165(1):123133. [PubMed: 15078903] 
96. Damen E, Krieger E, Nielsen JE, Eygensteyn J, van Leeuwen JE. The human Vps29 retromer component is a metallo-phosphoesterase for a cation-independent mannose 6-phosphate receptor substrate peptide. Biochem J. 2006; 398(3):399-409. [PubMed: 16737443]

97. Bugarcic A, Zhe Y, Kerr MC, Griffin J, Collins BM, Teasdale RD. Vps26A and Vps26B subunits define distinct retromer complexes. Traffic. 2011; 12(12):1759-1773. doi:10.1111/j. 1600-0854.2011.01284.x. [PubMed: 21920005]

98. Seaman MN. Cargo-selective endosomal sorting for retrieval to the Golgi requires retromer. J Cell Biol. 2004; 165(1):111-122. [PubMed: 15078902]

99. Rink J, Ghigo E, Kalaidzidis Y, Zerial M. Rab conversion as a mechanism of progression from early to late endosomes. Cell. 2005; 122(5):735-749. [PubMed: 16143105]

100. Roux A, Cappello G, Cartaud J, Prost J, Goud B, Bassereau P. A minimal system allowing tubulation with molecular motors pulling on giant liposomes. Proc Natl Acad Sci USA. 2002; 99(8):5394-5399. doi:10.1073/pnas.082107299. [PubMed: 11959994]

101. Delevoye C, Miserey-Lenkei S, Montagnac G, Gilles-Marsens F, Paul-Gilloteaux P, Giordano F, Waharte F, Marks MS, Goud B, Raposo G. Recycling endosome tubule morphogenesis from sorting endosomes requires the kinesin motor KIF13A. Cell Rep. 2014; 6(3):445-454. doi: 10.1016/j.celrep.2014.01.002. [PubMed: 24462287]

102. Hoepfner S, Severin F, Cabezas A, Habermann B, Runge A, Gillooly D, Stenmark H, Zerial M. Modulation of receptor recycling and degradation by the endosomal kinesin KIF16B. Cell. 2005; 121(3):437-450. doi:10.1016/j.cell.2005.02.017. [PubMed: 15882625]

103. Perez Bay AE, Schreiner R, Mazzoni F, Carvajal-Gonzalez JM, Gravotta D, Perret E, Lehmann Mantaras G, Zhu YS, Rodriguez-Boulan EJ. The kinesin KIF16B mediates apical transcytosis of transferrin receptor in AP-1B-deficient epithelia. EMBO J. 2013; 32(15):2125-2139. doi: 10.1038/emboj.2013.130. [PubMed: 23749212]

104. Schonteich E, Wilson GM, Burden J, Hopkins CR, Anderson K, Goldenring JR, Prekeris R. The Rip11/Rab11-FIP5 and kinesin II complex regulates endocytic protein recycling. J Cell Sci. 2008; 121(Pt 22):3824-3833. doi:10.1242/jcs.032441. [PubMed: 18957512]

105. Tooze J, Hollinshead M. Tubular early endosomal networks in AtT20 and other cells. J Cell Biol. 1991; 115(3):635-653. [PubMed: 1918157]

106. Hong Z, Yang Y, Zhang C, Niu Y, Li K, Zhao X, Liu JJ. The retromer component SNX6 interacts with dynactin p150(Glued) and mediates endosome-to-TGN transport. Cell Res. 2009; 19(12): 1334-1349. doi:10.1038/cr.2009.130. [PubMed: 19935774]

107. Skanland SS, Walchli S, Brech A, Sandvig K. SNX4 in complex with clathrin and dynein: implications for endosome movement. PLoS ONE. 2009; 4(6):e5935. doi:10.1371/journal.pone. 0005935. [PubMed: 19529763]

108. Roux A, Koster G, Lenz M, Sorre B, Manneville JB, Nassoy P, Bassereau P. Membrane curvature controls dynamin polymerization. Proc Natl Acad Sci USA. 2010; 107(9):4141-4146. doi: 10.1073/pnas.0913734107. [PubMed: 20160074]

109. Boucrot E, Ferreira AP, Almeida-Souza L, Debard S, Vallis Y, Howard G, Bertot L, Sauvonnet N, McMahon HT. Endophilin marks and controls a clathrin-independent endocytic pathway. Nature. 2015; 517(7535):460-465. doi:10.1038/nature14067. [PubMed: 25517094]

110. Neumann S, Schmid SL. Dual role of BAR domain-containing proteins in regulating vesicle release catalyzed by the GTPase, dynamin-2. J Biol Chem. 2013; 288(35):25119-25128. doi: 10.1074/jbc.M113.490474. [PubMed: 23861397]

111. Renard HF, Simunovic M, Lemiere J, Boucrot E, Garcia-Castillo MD, Arumugam S, Chambon V, Lamaze C, Wunder C, Kenworthy AK, Schmidt AA, McMahon HT, Sykes C, Bassereau P, Johannes L. Endophilin-A2 functions in membrane scission in clathrin-independent endocytosis. Nature. 2015; 517(7535):493-496. doi:10.1038/nature14064. [PubMed: 25517096]

112. Daumke O, Lundmark R, Vallis Y, Martens S, Butler PJ, McMahon HT. Architectural and mechanistic insights into an EHD ATPase involved in membrane remodelling. Nature. 2007; 449(7164):923-927. doi:10.1038/nature06173. [PubMed: 17914359]

113. Pant S, Sharma M, Patel K, Caplan S, Carr CM, Grant BD. AMPH-1/Amphiphysin/Bin1 functions with RME-1/Ehd1 in endocytic recycling. Nat Cell Biol. 2009; 11(12):1399-1410. doi: 10.1038/ncb1986. [PubMed: 19915558] 
114. Cai B, Xie S, Caplan S, Naslavsky N. GRAF1 forms a complex with MICAL-L1 and EHD1 to cooperate in tubular recycling endosome vesiculation. Front Cell Dev Biol. 2014; 2:22. doi: 10.3389/fcell.2014.00022. [PubMed: 25364729]

115. Paoluzi S, Castagnoli L, Lauro I, Salcini AE, Coda L, Fre S, Confalonieri S, Pelicci PG, Di Fiore PP, Cesareni G. Recognition specificity of individual EH domains of mammals and yeast. EMBO J. 1998; 17(22):6541-6550. doi:10.1093/emboj/17.22.6541. [PubMed: 9822599]

116. Salcini AE, Confalonieri S, Doria M, Santolini E, Tassi E, Minenkova O, Cesareni G, Pelicci PG, Di Fiore PP. Binding specificity and in vivo targets of the EH domain, a novel protein-protein interaction module. Genes Dev. 1997; 11(17):2239-2249. [PubMed: 9303539]

117. Naslavsky N, Caplan S. EHD proteins: key conductors of endocytic transport. Trends Cell Biol. 2011; 21(2):122-131. doi:10.1016/j.tcb.2010.10.003. [PubMed: 21067929]

118. Cai B, Caplan S, Naslavsky N. cPLA2alpha and EHD1 interact and regulate the vesiculation of cholesterol-rich, GPI-anchored, protein-containing endosomes. Mol Biol Cell. 2012; 23(10): 1874-1888. doi:10.1091/mbc.E11-10-0881. [PubMed: 22456504]

119. Giridharan SS, Cai B, Vitale N, Naslavsky N, Caplan S. Cooperation of MICAL-L1, syndapin2, and phosphatidic acid in tubular recycling endosome biogenesis. Mol Biol Cell. 2013; 24(11): 1776-1790. S1771-S1715. doi:10.1091/mbc.E13-01-0026. [PubMed: 23596323]

120. Jakobsson J, Ackermann F, Andersson F, Larhammar D, Low P, Brodin L. Regulation of synaptic vesicle budding and dynamin function by an EHD ATPase. J Neurosci. 2011; 31(39):13972_ 13980. doi:10.1523/JNEUROSCI.1289-11.2011. [PubMed: 21957258]

121. Zajac AL, Goldman YE, Holzbaur EL, Ostap EM. Local cytoskeletal and organelle interactions impact molecular-motor-driven early endosomal trafficking. Curr Biol. 2013; 23(13):1173-1180. doi:10.1016/j.cub.2013.05.015. [PubMed: 23770188]

122. Agromayor M, Carlton JG, Phelan JP, Matthews DR, Carlin LM, Ameer-Beg S, Bowers K, Martin-Serrano J. Essential role of hIST1 in cytokinesis. Mol Biol Cell. 2009; 20(5):1374-1387. doi:10.1091/mbc.E08-05-0474. [PubMed: 19129480]

123. Reid E, Connell J, Edwards TL, Duley S, Brown SE, Sanderson CM. The hereditary spastic paraplegia protein spastin interacts with the ESCRT-III complex-associated endosomal protein CHMP1B. Hum Mol Genet. 2005; 14(1):19-38. doi:10.1093/hmg/ddi003. [PubMed: 15537668]

124. Renvoise B, Parker RL, Yang D, Bakowska JC, Hurley JH, Blackstone C. SPG20 protein spartin is recruited to midbodies by ESCRT-III protein Ist1 and participates in cytokinesis. Mol Biol Cell. 2010; 21(19):3293-3303. doi:10.1091/mbc.E09-10-0879. [PubMed: 20719964]

125. Liu J, Sun Y, Drubin DG, Oster GF. The mechanochemistry of endocytosis. PLoS Biol. 2009; 7(9):e1000204. doi:10.1371/journal.pbio.1000204. [PubMed: 19787029]

126. Kaksonen M, Sun Y, Drubin DG. A pathway for association of receptors, adaptors, and actin during endocytic internalization. Cell. 2003; 115(4):475-487. [PubMed: 14622601]

127. Kaksonen M, Toret CP, Drubin DG. Harnessing actin dynamics for clathrin-mediated endocytosis. Nat Rev Mol Cell Biol. 2006; 7(6):404-414. [PubMed: 16723976]

128. Rowland AA, Chitwood PJ, Phillips MJ, Voeltz GK. ER contact sites define the position and timing of endosome fission. Cell. 2014; 159(5):1027-1041. doi:10.1016/j.cell.2014.10.023. [PubMed: 25416943]

129. Friedman JR, Lackner LL, West M, DiBenedetto JR, Nunnari J, Voeltz GK. ER tubules mark sites of mitochondrial division. Science. 2011; 334(6054):358-362. doi:10.1126/science.1207385. [PubMed: 21885730]

130. Chen D, Xiao H, Zhang K, Wang B, Gao Z, Jian Y, Qi X, Sun J, Miao L, Yang C. Retromer is required for apoptotic cell clearance by phagocytic receptor recycling. Science. 2010; 327(5970): 1261-1264. doi:10.1126/science.1184840. [PubMed: 20133524]

131. Lieu ZZ, Gleeson PA. Identification of different itineraries and retromer components for endosome-to-Golgi transport of TGN38 and Shiga toxin. Eur J Cell Biol. 2010; 89(5):379-393. doi:10.1016/j.ejcb.2009.10.021. [PubMed: 20138391]

132. Niemes S, Langhans M, Viotti C, Scheuring D, San Wan Yan M, Jiang L, Hillmer S, Robinson DG, Pimpl P. Retromer recycles vacuolar sorting receptors from the trans-Golgi network. Plant J. 2010; 61(1):107-121. doi:10.1111/j.1365-313X.2009.04034.x. [PubMed: 19796370] 
133. Oliviusson P, Heinzerling O, Hillmer S, Hinz G, Tse YC, Jiang L, Robinson DG. Plant retromer, localized to the prevacuolar compartment and microvesicles in Arabidopsis, may interact with vacuolar sorting receptors. Plant Cell. 2006; 18(5):1239-1252. [PubMed: 16582012]

134. Okada H, Zhang W, Peterhoff C, Hwang JC, Nixon RA, Ryu SH, Kim TW. Proteomic identification of sorting nexin 6 as a negative regulator of BACE1-mediated APP processing. FASEB J. 2010; 24(8):2783-2794. doi:10.1096/fj.09-146357. [PubMed: 20354142]

135. Jaillais Y, Santambrogio M, Rozier F, Fobis-Loisy I, Miege C, Gaude T. The retromer protein VPS29 links cell polarity and organ initiation in plants. Cell. 2007; 130(6):1057-1070. [PubMed: 17889650]

136. Kleine-Vehn J, Leitner J, Zwiewka M, Sauer M, Abas L, Luschnig C, Friml J. Differential degradation of PIN2 auxin efflux carrier by retromer-dependent vacuolar targeting. Proc Natl Acad Sci USA. 2008; 105(46):17812-17817. doi:10.1073/pnas.0808073105. [PubMed: 19004783]

137. Gleason RJ, Akintobi AM, Grant BD, Padgett RW. BMP signaling requires retromer-dependent recycling of the type I receptor. Proc Natl Acad Sci USA. 2014; 111(7):2578-2583. doi:10.1073/ pnas.1319947111. [PubMed: 24550286]

138. Wang S, Tan KL, Agosto MA, Xiong B, Yamamoto S, Sandoval H, Jaiswal M, Bayat V, Zhang K, Charng WL, David G, Duraine L, Venkatachalam K, Wensel TG, Bellen HJ. The retromer complex is required for rhodopsin recycling and its loss leads to photoreceptor degeneration. PLoS Biol. 2014; 12(4):e1001847. doi:10.1371/journal.pbio.1001847. [PubMed: 24781186]

139. Florian V, Schluter T, Bohnensack R. A new member of the sorting nexin family interacts with the C-terminus of P-selectin. Biochem Biophys Res Commun. 2001; 281(4):1045-1050. doi: 10.1006/bbrc.2001.4467. [PubMed: 11237770]

140. McGough IJ, Steinberg F, Gallon M, Yatsu A, Ohbayashi N, Heesom KJ, Fukuda M, Cullen PJ. Identification of molecular heterogeneity in SNX27-retromer-mediated endosome-to-plasmamembrane recycling. J Cell Sci. 2014; 127(22):4940-4953. doi:10.1242/jcs.156299. [PubMed: 25278552]

141. Canuel M, Lefrancois S, Zeng J, Morales CR. AP-1 and retromer play opposite roles in the trafficking of sortilin between the Golgi apparatus and the lysosomes. Biochem Biophys Res Commun. 2008; 366(3):724-730. [PubMed: 18078806]

142. Verges M, Luton F, Gruber C, Tiemann F, Reinders LG, Huang L, Burlingame AL, Haft CR, Mostov KE. The mammalian retromer regulates transcytosis of the polymeric immunoglobulin receptor. Nat Cell Biol. 2004; 6(8):763-769. [PubMed: 15247922]

143. Pocha SM, Wassmer T, Niehage C, Hoflack B, Knust E. Retromer controls epithelial cell polarity by trafficking the apical determinant Crumbs. Curr Biol. 2011; 21(13):1111-1117. doi:10.1016/ j.cub.2011.05.007. [PubMed: 21700461]

144. Nothwehr SF, Hindes AE. The yeast VPS5/GRD2 gene encodes a sorting nexin-1-like protein required for localizing membrane proteins to the late Golgi. J Cell Sci. 1997; 110(Pt 9):10631072. [PubMed: 9175702]

145. Voos W, Stevens TH. Retrieval of resident late-Golgi membrane proteins from the prevacuolar compartment of Saccharomyces cerevisiae is dependent on the function of Grd19p. J Cell Biol. 1998; 140(3):577-590. [PubMed: 9456318]

146. Cereghino JL, Marcusson EG, Emr SD. The cytoplasmic tail domain of the vacuolar protein sorting receptor Vps10p and a subset of VPS gene products regulate receptor stability, function, and localization. Mol Biol Cell. 1995; 6(9):1089-1102. [PubMed: 8534908]

147. Ueno K, Saito M, Nagashima M, Kojima A, Nishinoaki S, Toshima JY, Toshima J. V-ATPasedependent luminal acidification is required for endocytic recycling of a yeast cell wall stress sensor, Wsc1p. Biochem Biophys Res Commun. 2014; 443(2):549-555. doi:10.1016/j.bbrc. 2013.12.008. [PubMed: 24326069] 


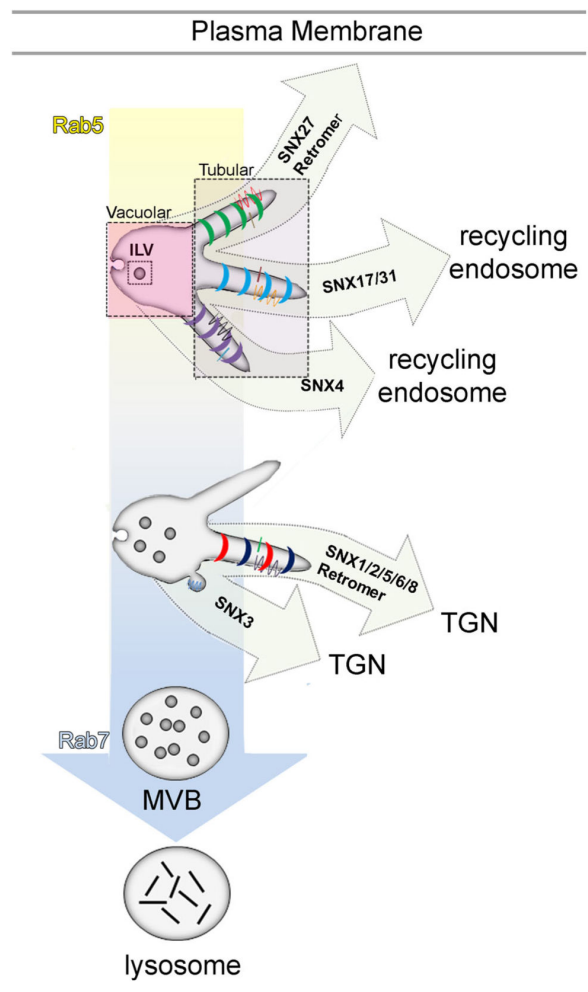

Fig. 1.

Sorting nexin mediated endosome export pathways. As an early, RAB5 GTPase-positive, endosome matures into a RAB7-GTPase-positive endosome, integral membrane proteins and lipids are exported from it via tubules and vesicles, collectively referred to here as 'endosome-derived transport carriers' (ETCs). Whereas cargo is sorted into the tubular domain of the endosome for export, the vacuolar domain of the endosome, containing solutes and intralumenal vesicles (ILVs) produced by the multi-vesicular body (MVB) sorting pathway, retains material and ultimately fuses with the lysosome where its contents are degraded via the lysosomal degradation pathway. Distinct requirements for three different sorting nexins, SNX27, SNX17 (and its paralog, SNX31), and SNX4, distinguish three export pathways from the early/sorting endosome that ferry cargo to the plasma membrane or the recycling endosome. At least two distinct export pathways operate on more mature endosomes, defined by requirements for the SNX-BAR proteins, SNX1, SNX2, SNX5, and SNX6, or the PX-only sorting nexin, SNX3. These pathways mediate retrograde trafficking of cargo from the endosome to the trans Golgi network (TGN). Where indicated, the retromer sorting device associates with the sorting nexin and contributes to cargo packaging 

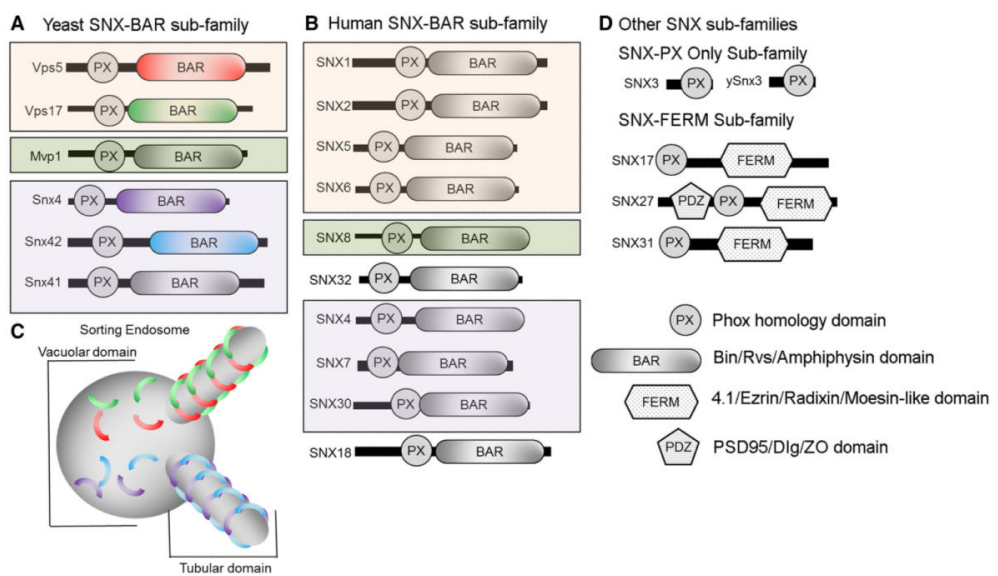

Fig. 2.

Key features of sorting nexins that mediate export from the endosome. All sorting nexins contain an evolutionarily conserved Phox-homology (PX) domain that recognizes phosphatidylinositol 3-phosphate. a, b Members of the SNX-BAR sub-family of sorting nexins also contain a Bin-Amphiphysin-Rvs (BAR) dimerization domain that displays a curved surface and oligomerizes to coat the membrane of an endosome-derived transport carrier. Subsets of SNX-BARs (colored boxes) have been shown to homo- or heterodimerize. c Model of tubular ETC formation by SNX-BARs. SNX-BAR protomers coat both the vacuolar and tubular domains of the endosome and oligomerize to coat the tubular ETCs. Restricted oligomerization of SNX-BAR protomers, and dependence on other factors such as retromer, define distinct export pathways. d Other evolutionarily conserved SNX proteins implicated in endosome export. Members of the PX-only subfamily are comprised of a single PX domain. So far, SNX3 (and its yeast homolog, ySnx3) are the only members of this sub-family to be implicated in cargo export. Members of the SNX-FERM sub-family contain a C-terminal FERM (band4.1/ezrin/radixin/moesin) domain, which is a protein interaction module that is used for cargo recognition 


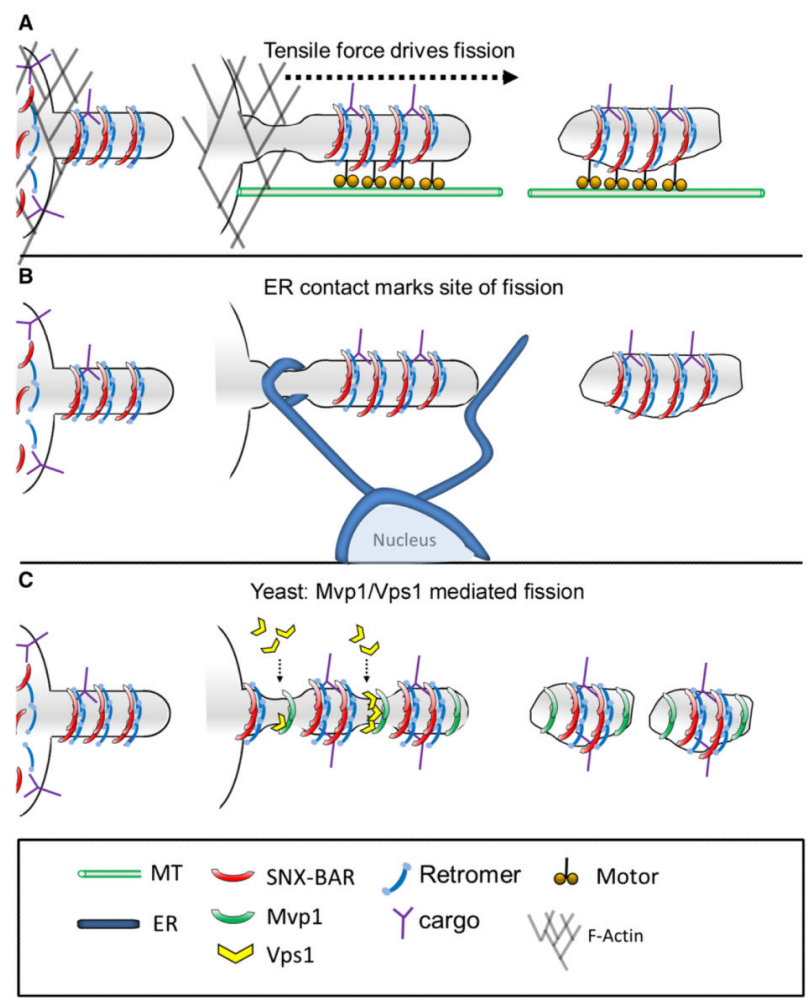

Fig. 3.

Modes of ETC fission. Depicted are three types of fission events proposed to elicit fission of tubular endosome-derived transport carriers from the mother endosome. a Tensile force produced by coordinated action of F-actin and microtubule-dependent motors. Whereas long range movement of the endosome is mediated by microtubule-dependent motors, such as dynein and kinesins, filamentous actin restricts the motility of endosomes by 'caging' or tethering the endosome $\left[{ }^{121}\right]$. Localized increase in microtubule-dependent motor traction and corresponding increase in tensile force relative to the tethered vacuolar domain leads to ETC fission. Local endosome-associated actin dynamics, generated by ARP2/3 and the WASH complex, might also propel the ETC away from the mother endosome to drive fission. b ETC fission occurs at sites where the ETC is contacted by a tubule of the endoplasmic reticulum (ER), however, the role of the ER contact sites in ETC fission has yet to be elucidated. $\mathbf{c}$ In yeast, ETC fission is mediated by the dynamin-related protein, Vps1. The SNX-BAR protein, Mvp1, is proposed to facilitate oligomerization of Vps1 on the ETC membrane by constricting the diameter of the tubule, thereby promoting fission. Models are not drawn to scale 


\section{Table 1}

Diversity of retrograde cargo sorting mechanisms

\begin{tabular}{|c|c|c|c|c|}
\hline Cargo & Sorting machinery & $\begin{array}{l}\text { Sorting motif/ } \\
\text { region }\end{array}$ & Recognition & References \\
\hline Cation-independent mannose phosphate receptor & Retromer/SNX1 or SNX2 & WLM & $\begin{array}{l}\text { Retromer- } \\
\text { VPS35 }\end{array}$ & {$[22,92]$} \\
\hline CED1 & Retromer/SNX1 or SNX6 & - & - & {$\left[{ }^{130}\right]$} \\
\hline TGN38 & Retromer SNX2 & - & - & {$\left[{ }^{131}\right]$} \\
\hline Vacuolar sorting receptor & SNX1 and SNX2 & - & $\begin{array}{l}\text { Retromer- } \\
\text { VPS35 }\end{array}$ & {$\left[{ }^{132}, 133\right]$} \\
\hline BACE1 & Retromer/SNX6 & - & - & {$\left[{ }^{134}\right]$} \\
\hline PIN1 and 2 & VPS29 and SNX1 & - & - & {$[135,136]$} \\
\hline SMA-6 & Retromer/SNX3 & - & $\begin{array}{l}\text { Retromer- } \\
\text { VPS35 }\end{array}$ & {$\left[{ }^{137}\right]$} \\
\hline Rhodopsin 1 & Retromer/SNX3/SNX1 & - & - & {$\left[{ }^{138}\right]$} \\
\hline Wntless & Retromer/SNX3 & - & SNX3 & {$\left[{ }^{63}\right]$} \\
\hline APOER2, LRP1, P-selectin, patched, APP & SNX17 & $\begin{array}{l}\text { NPXY, FxNaa } \\
(\mathrm{F} / \mathrm{Y})\end{array}$ & SNX17 & $\begin{array}{c}73,75,76,79,81,83, \\
139]\end{array}$ \\
\hline Beta 1 integrins & $\begin{array}{l}\text { SNX17/not retromer, SNX1-2 } \\
\text { or SNX5-6 }\end{array}$ & Cyto tail & SNX17 & {$\left[{ }^{74}\right]$} \\
\hline $\begin{array}{l}\text { TRAILR1, CD97, beta-2 adrenergic receptor, } \\
\text { GLUT1, MCT1 }\end{array}$ & Retromer/SNX27 & PDZ ligand & - & {$[84,140]$} \\
\hline SorLA & Retromer & FANSHY & VPS29 & {$\left[{ }^{91}\right]$} \\
\hline Sortilin & Retromer & FLV or YXX $\phi$ & VPS35/26 & {$[92,141]$} \\
\hline pIgA receptor & Retromer & - & - & {$\left[{ }^{142}\right]$} \\
\hline Crumbs & Retromer & Cyto tail & Retromer & {$\left[{ }^{143}\right]$} \\
\hline DMT1-II & Retromer & YLL & VPS35/26 & {$[93]$} \\
\hline \multicolumn{5}{|l|}{ Yeast cargo } \\
\hline Pep12, Ste13 & Retromer/Snx3 & - & - & {$[41,144,145]$} \\
\hline Kex2 & Retromer/Snx3/Vps17?/Mvp1 & - & - & {$\left[{ }^{145}\right]$} \\
\hline Fet3/Ftr1 & Retromer/Vps17/Vps5/Snx3 & Ftr1 cyto tail & $\operatorname{Snx} 3$ & {$\left[{ }^{60}\right]$} \\
\hline Vps10 & $\begin{array}{l}\text { Retromer/Vps17/Vps5?/Mvp1/ } \\
\text { NOT Snx3 }\end{array}$ & FVYF & - & {$\left[{ }^{146}\right]$} \\
\hline Can1 & Retromer/Ere1 OR Snx4 family & - & - & {$\left[{ }^{43}\right]$} \\
\hline Snc1 & Snx4 & - & Snx4 & {$\left[{ }^{41}\right]$} \\
\hline Wsc1 & Retromer & - & - & {$\left[{ }^{147}\right]$} \\
\hline
\end{tabular}

Cell Mol Life Sci. Author manuscript; available in PMC 2016 September 01. 